\title{
Role of GST in Economic Development
}

\author{
${ }^{1}$ Shobha Sarita Bhuinyan
}

\begin{abstract}
The Goods and Services Tax (GST) is the biggest reform in India's indirect tax structure. GST would be applicable on the supply of goods or services as against the previous concept of tax on the manufacture and sale of goods or provision of services. It is a destination based consumption tax. GST would apply to all goods other than exempted goods i.e. alcoholic liquor for human consumption and specified petroleum products. It would apply to all services barring a few to be specified. The impact of GST would be a major game changer for the economy for accelerating the economic growth and generating more and more employment. GST helps the economy to grow in more efficient manner by ameliorating the tax accumulation as it abolishes all the tax barriers among states and integrate country via single tax rate i.e."One tax ,one nation". It benefits the Indian economy in many ways e.g. reducing the price for domestic necessities, uniform tax rate, reduce multiple taxes etc .GST will affect many sectors in positive or negative manner. After GST implementation some products price have been reduced like branded goods, hotels, personal hair products, soap etc. some products price have been increased like mobile bills, aerated drinks, internet, air tickets. This paper focuses on the benefits, challenges and roll of GST on Indian economic development.
\end{abstract}

Keywords: GST; Gross GST revenue; Tax barriers; Economic development.

Corresponding Author: ${ }^{1}$ Shobha Sarita Bhuinyan Assistant Professor,SSLNT M College,Dhanbad E-Mail: shobhasarita29@gmail.com

\section{Introduction}

GST stands for Goods and Services Tax, it's a single tax on supply of goods and services right from manufacturer up to last consumer. [1] Goods and Services Tax is a comprehensive, multistage, destination-based tax that will be levied on every value addition, Credits of input taxes paid at each stage will be available in the subsequent stage of value addition, which makes GST essentially a tax only on value addition at each stage. The final consumer will thus bear only the GST charged by the last dealer in the supply chain, with set-off benefits at all the previous stages. GST is an important arm to free the nation from the terrorism of tax. This can be seen as a victory of the democratic ethos of India and for everyone. Which aims to turn India 
into one common market,[2] scrapping a host of taxes e.g. excise, sales tax, VAT, octroi , entry fees and replacing it with a single tax the GST. The amendments to the GST Constitutional Amendment Bill scrapped an earlier decided upon 1\% interstate levy, provided for compulsory 5-year compensation to states for revenue losses from bringing in GST, besides providing for a dispute redressal mechanism to be set up by the GST Council. The set of changes brought in by the Government to an earlier bill, proposed among others to delete Clause 18 of the original bill that included compensating the manufacturing states with $1 \%$ additional duty for a period of two years or more for revenue losses. The Congress and several other opposition parties had demanded a standing appellate authority headed by a serving or retired Supreme Court Judge to adjudicate on such cases. The bill seems to concede as much without spelling out the terms of the authority. "We have left the terms and conditions to be decided by the GST Council, where the centre and states are both represented," pointed out officials. The amendment also clarifies that state's share of GST tax will not form part of the Consolidated Fund of India. "The amount apportioned to a state shall not form part of the consolidated Fund of India...." the amendment said. GST itself has been in the works for more than a decade now and had been held hostage for long due to apprehension of states as well as bickering over its terms and specific wording between parties. However, the interesting point is that almost all parties as well as Indian business and intelligentsia were united in the need for the taxation measure. The move is expected to reduce black money flow as the tax measure will capture. Prime Minister Narendra Modi's Speech at GST launch throws light on the importance of GST. He said, 'There was confusion in everybody's mind. The foreign investors used to be confused about different systems in different states. Today we are moving ahead to get rid of that situation. Once GST is in place, all sorts of taxes like sales tax, VAT etc. will cease to exist. Long wait by vehicles at toll plazas will end, where fuels worth crores of rupees are wasted and that causes damage to the environment as well. Now we will be free from all of those troubles as the entire country will have a similar tax structure. Sometimes certain items, especially the perishable ones that were supposed to reach their destination in time, were delayed because of the time taken for processing and it resulted in losses at both ends. Today we are getting rid of all that. The country is moving a step forward towards a modern taxation system. This is a system that is simpler, more transparent. It will help us curbing black money and corruption and reward honesty. It will generate interest and enthusiasm to do business honestly. It will bring in a new culture of governance.[4] We have lived tax terrorism and inspector raj. Today, due to the transparency of GST, due to technologically proven trial, grey areas are ending. GST has an inherent strength of eliminating the possibility of ordinary businessmen being harassed by the officers.

Despite many voices being raised for it and against it, one can't deny that this tax reform caused to amend the tax rates and bring a unified front on many consumer goods across the nation. Let us breakdown GST in layman language. Before this reform, whenever a consumer buys a commodity or a service, they had to pay for not 
only the cost price but also service tax, CST, excise, and many such indirect taxes. Under the umbrella of GST, all such charges have been combined [5].

Thus, removing all the financial hassles for the end consumer.GST is a destinationbased tax. This indicates that the tax for a product will be levied only at the point where it is sold i.e., the point of consumption. One of its main focus was the development of Small and Medium-scale Enterprises (SMEs).[6]

There are four types of GST:

I. Central Goods and Service Tax (CGST)

II. State Goods and Service Tax (SGST)

III.Union Territory Goods and Service Tax (UGST)

IV.Integrated Goods and Service Tax (IGST)

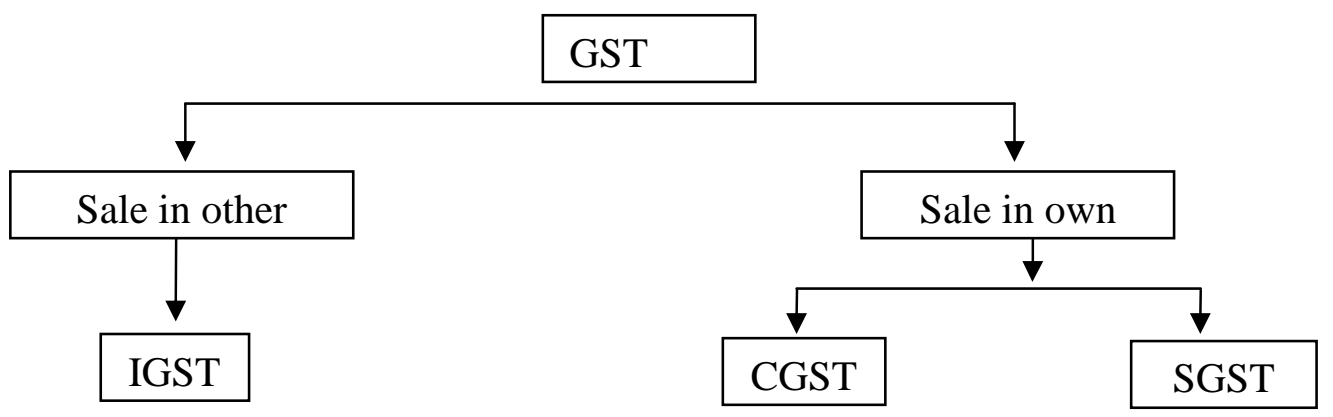

The input credit under the Goods and Service Tax is the system which ensures that dual taxation cannot be imposed on same goods and services. Under this arrangement it is ensured, that how much money the governments (centre/state) have to get in the form of tax, the entire burden of tax lies on the last buyer. Therefore it is ensure that $\mathrm{n}$ the chain of purchase of goods and services, the burden of tax does not fall on the traders falling in the middle.[7] Input credit is also called input tax credit.

To understand the input credit, it is necessary to know that what is the input tax and output tax.

A. Input Tax: The tax paid on own a purchase is called the input tax in the language of taxation.

B. Output Tax: The tax collected on own sales are called the output tax in language of taxation.

Actually, input credits are such credits, which the businessman can use to pay their output tax liability. This credit is received in return for payment on that tax which he has to pay earlier for purchases of goods or receive the service. Since this credit 
has been given to him in consideration of input tax, hence it is called input tax credit.[8, 9]

The government has classified the rates of GST in five categories:

These are $-0 \%, 5 \%, 12 \%, 18 \%$ and $28 \%$.

\section{Objective of study}

1. To study the importance of GST.

2. To study the GST collection in India.

3. To study the role of GST in economic development.

\section{Methodology}

Secondary data is extensively used for the study. Statistical tools- Table, Bar diagram, Line diagram and Time series.

\section{Importance of GST-}

\section{Make in India -}

i. It helps to create a unified common national market for India, giving a boost to Foreign Investment and "Make in India" campaign.

ii. Prevents cascading of taxes as Input Tax Credit will be available across goods and services at every stage of supply

iii. Harmonization of laws, procedures and rates of tax.[10]

iv. It helps to boost export and manufacturing activity, generate more employment and thus increase GDP with gainful employment leading to substantive economic growth.[11,12,13]

v. It helps in poverty eradication by generating more employment and more financial resources.

vi. More efficient neutralization of taxes especially for exports thereby making our products more competitive in the international market and give boost to Indian Exports.

vii. It improves the overall investment climate in the country which will naturally benefit the development in the states.[14,15]

viii. Uniform SGST and IGST rates reduce the incentive for evasion by eliminating rate arbitrage between neighboring States and that between intra and inter-States sales. Average tax burden on companies is likely to come down which is expected to reduce prices and lower prices mean more consumption which in turn means more production thereby helping in the 
growth of the industries.[16,17,18] This will create India as a "Manufacturing Hub".

ix. Uplift of the Lesser Developed States

x. A Launching Pad for Startups.

xi. Hike in Indian Exports.

xii. It increases competition in market which is the base of innovation.

\section{Ease of Doing Business -}

i. Simpler tax regime with fewer exemptions.

ii. Reductions in the multiplicity of taxes that are at present governing our indirect tax system leading to simplification and uniformity.[18,19,20]

iii. Reduction in compliance costs - No multiple records keeping for a variety of taxes - so lesser investment of resources and manpower in maintaining records.

iv. All interaction to be through the common GSTN portal - so less public interface between the taxpayer and the tax administration.

v. It will improve environment of compliance as all returns to be filed online, input credits to be verified online, encouraging more paper trail of transactions [21,22].

vi. Common procedures for registration of taxpayers, refund of taxes, uniform formats of tax return, common tax base, common system of classification of GST will lend greater certainty to taxation system [19, 21].

vii. Timelines to be provided for important activities like obtaining registration, refunds, etc. Electronic matching of input tax credits all across India thus making the process more transparent and accountable.

Viii. The Overall Drop in the Marginal Tax Rate

ix. Removal of Cascading Effect of Taxes.

x. Comparatively More Transparent \& Fully Online Taxation System.

xi. Prescribed Routine for the E-Commerce Sector.

xii. Reorganization of Business and Industries as a Whole.

\section{Benefits to Customers}


i. Final price of goods is lower due to seamless flow of input tax credit between the manufacturer, retailer and service provider.

ii. It is expected that a relatively large segment of small retailers will be either exempted from tax or will suffer very low tax rated under a compounding scheme purchases from such entities will cost less for the consumers.

iii. Average tax burden on companies is likely to come down which is expected to reduce prices and lower prices mean more consumption.

iv. Similar Pricing in the Nationwide Market.

v. Greater Ease in Buying Goods and Services.

vi. Consumer is able to know how much tax is paid by him.

Table: GST Collection of India ( in crore rupees)

\begin{tabular}{|l|l|l|l|l|}
\hline FY & $2017-18$ & $2018-19$ & $2019-20$ & $2020-21$ \\
\hline $\begin{array}{l}\text { GST } \\
\text { collection }\end{array}$ & $7,40,650.00$ & $11,77,369.00$ & $12,22,131.00$ & $11,36,803.00$ \\
\hline
\end{tabular}

Source: http://pib.gov.in

PRID- 1609919

GST collection of India(crore rupees) is shown in following bar diagram:

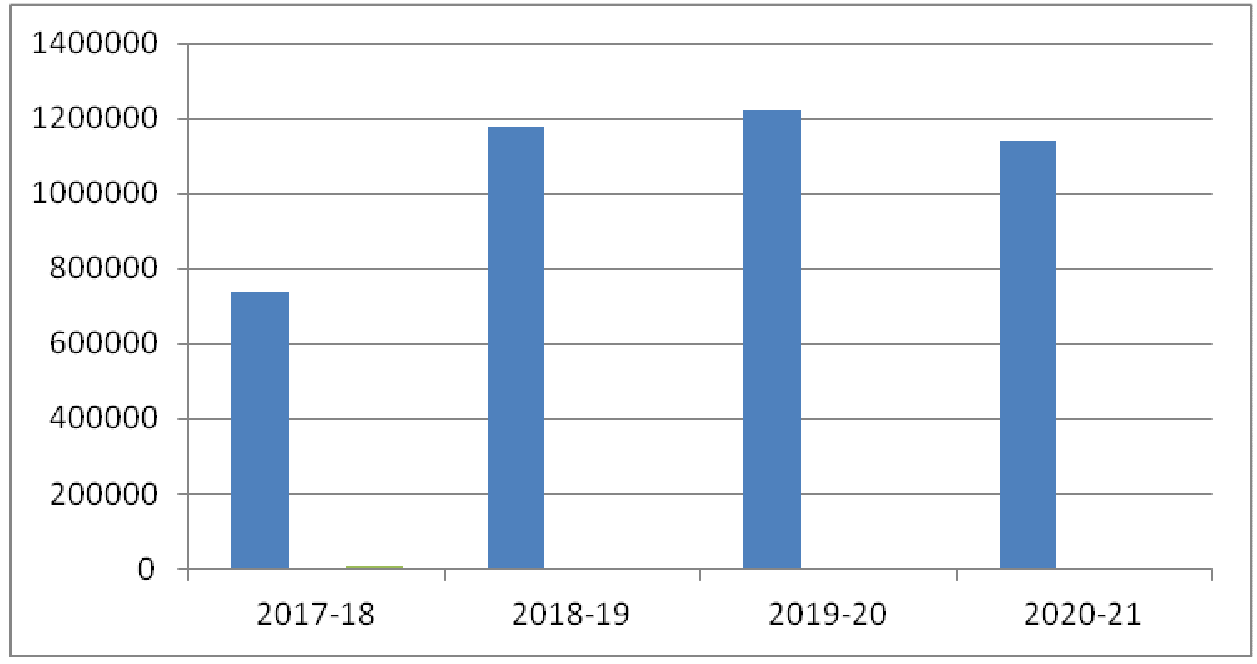

Source: http://pib.gov.in 
It is clear in the figure that there was upward trend in GST collection but in 2020-21 it declined due to COVID-19 and lockdown..

Estimation of GST collection for 2021-22 using Time series --

\begin{tabular}{|r|r|r|r|l|l|}
\hline FY & GST(Y) & X & $\mathrm{X}^{2}$ & $\mathrm{XY}$ & $\begin{array}{l}\text { Trend Values } \\
\mathrm{Y}=1069239+ \\
83707.4 \mathrm{X}\end{array}$ \\
\hline $2017-18$ & 740650 & -2 & 4 & 1481300 & 901824.2 \\
\hline $2018-19$ & 1177369 & -1 & 1 & 1177369 & 985531.6 \\
\hline $2019-20$ & 1222131 & 1 & 1 & 1222131 & 1152946.4 \\
\hline $2020-21$ & 1136806 & 2 & 4 & 2273612 & 1236653.8 \\
\hline & $\sum \mathrm{Y}=4276956$ & $\sum \mathrm{X}=0$ & $\sum \mathrm{X}^{2}=10$ & $\begin{array}{l}\sum \mathrm{XY}= \\
837074\end{array}$ & \\
\hline
\end{tabular}

Source: Authors own calculation based on data collected.

$\mathrm{X}=$ Time, $\mathrm{N}=4$

Straight line equation is-

$\mathrm{Y}=a+b \mathrm{X}$

Value of $a$ and $B$ are found by following LS normal equations

$\mathrm{Na}+6 \sum \mathrm{X}=\sum \mathrm{Y}$

$a \sum X+B \sum \mathrm{X}^{2}=\sum \mathrm{XY}$

From equation (i)

$$
\begin{gathered}
\alpha=\frac{\Sigma Y}{N} \\
\alpha=\frac{4276956}{4}
\end{gathered}
$$




$$
\alpha=1069239
$$

From equation (ii)

$$
\begin{gathered}
B=\frac{\sum X Y}{\sum X^{2}} \\
B=\frac{837074}{10} \\
B=83707.4
\end{gathered}
$$

Trend line equation is --.-

$$
\begin{aligned}
& \mathrm{Y}=\alpha+\beta \mathbf{x} \\
& Y^{\prime}=1069239+83707.4 X \\
& \text { Slope }=83707.4 \\
& \text { Trend values for } \\
& \text { Y'2017-18 }=1069239+83707.4 \times-2=901824.2 \\
& \mathrm{Y}_{2018-19}^{\prime}=1069239+83707.4 \times-1=985531.6 \\
& \mathrm{Y}_{2019-20}=1069239+83707.4 \times 1=1152946.4 \\
& \mathrm{Y}_{2020-21}^{\prime}=1069239+83707.4 \times 2=1236653.8 \\
& \mathrm{Y}^{\prime} 2021-2022=1069239+83707.4 \times 3=1320361.2
\end{aligned}
$$

Estimate of GST collection for ${ }^{\mathrm{FY}} 2021-22$ is 1320361.2 crore

There is some discrepancy in actual GST and trend GST. I plot these trends in following line diagram.

\begin{tabular}{|r|l|l|l|}
\hline FY & Actual GST & Trend GST & Discrepancy \\
\hline $2017-18$ & 740650 & 901824.2 & Upward Trend \\
\hline $2018-19$ & 1177369 & 985531.6 & Downward Trend \\
\hline
\end{tabular}




\begin{tabular}{|l|l|l|l|}
\hline $2019-20$ & 1222131 & 1152946.4 & Downward Trend \\
\hline $2020-21$ & 1136806 & 1236653.8 & Upward Trend \\
\hline
\end{tabular}

Source: Authors own calculation based on data collected.

It is clear in the chart that in the beginning of GST implementation, GST collection was increasing but then it was increasing at a very slow rate and in 2020-21 it declined. Reason for that is COVID-19 and input credit tax evasion.

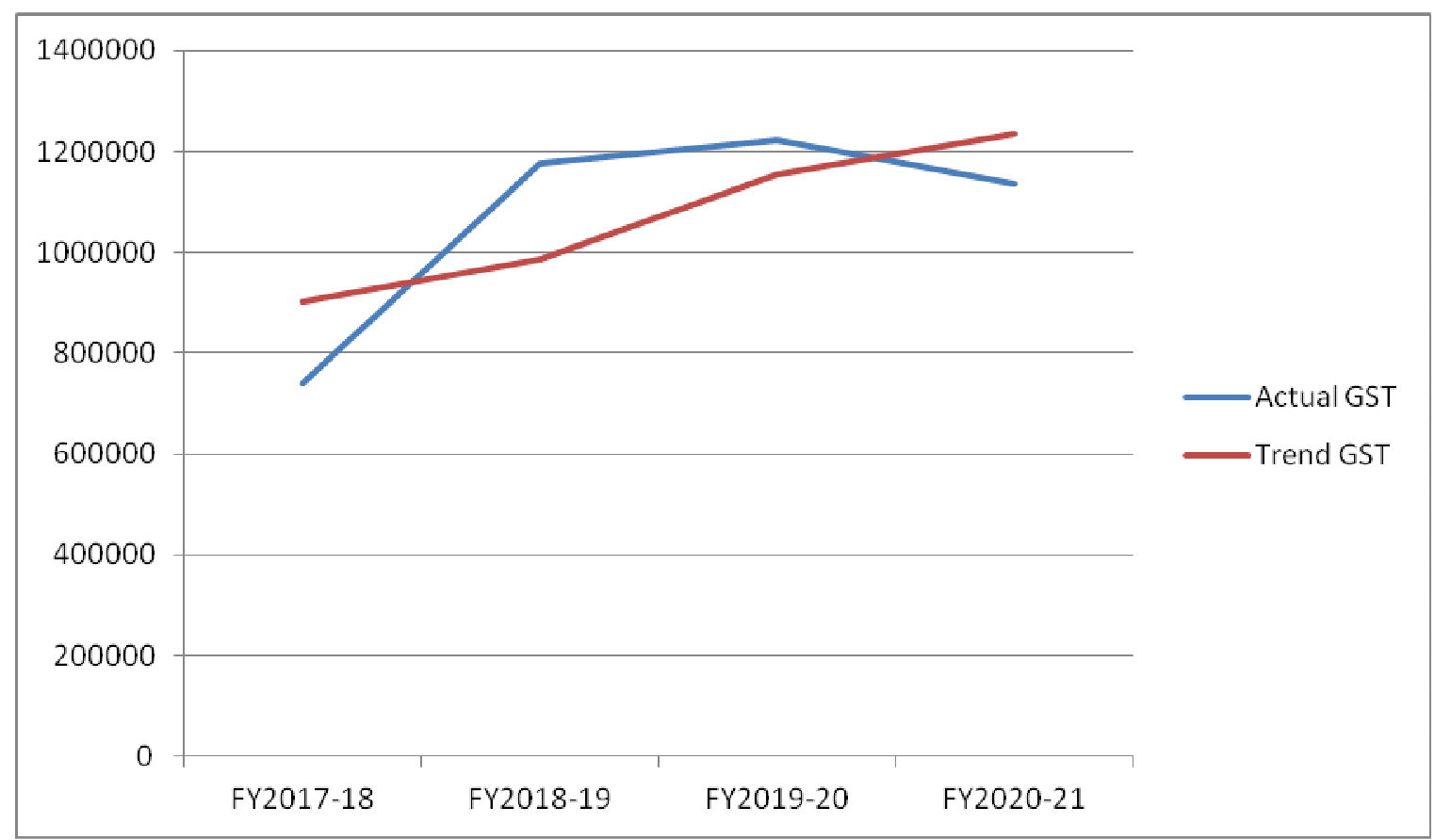

Source: Authors own calculation based on data collected.

\section{Suggestions}

- Petroleum, Liquor should be covered in GST.

- The "kacha bill" should be banned. This leads to income tax evasion from the seller and service tax from the consumer.

- There should be a proper billing system in GST in order to reduce Tax evasion from both consumers and sellers and root out corruption. 
- The States like Jharkhand as a producer of minerals, coals etc, should be fairly compensated from Centre for loss of revenue from implementation of GST.

\section{Conclusion}

Change is never easy. Despite major criticism, the GST tax regime, which is still just four years old, To clear the obstructions for development requires us to make hard decisions but only time will tell how successfully GST will turn out to be and how high it takes us on the economic scale on a global level. Tax policies play an important role on the economy through their impact. A good tax system should keep in view issues of income distribution and also endeavor to generate tax revenues to support government expenditure on public services and infrastructure development. Cascading tax revenues have differential impact in the economy. This results in loss of income and welfare of the affected economy. It is a major improvement over the pre- existing central excise duty at the national level and the sales tax system at the state level, the GST tax regime logical step towards a comprehensive indirect tax reform in the country. Upward GST trend line shows the positive economic growth.

\section{Acknowledgement}

We acknowledge our deepest gratitude to previous researchers on this subject whose work immensely benefited us.

\section{Declaration of Conflict of Interest}

The authors declared no potential conflicts of interest with respect to the research, authorship, and/or publication of this article.

\section{Funding}

The author received no financial support for the research, authorship, and/or publication of this article.

\section{References:}

[1] Gupta, S., Sarita, Singh M. K.,Komal (2017) Good and Service Tax: An International Comparative Analysis International Journal of Research in Finance \& Marketing Vol. 7 Issue 5, May - 2017, pp. 164 173.

[2] Shefali, D. "Impact of goods and service tax (GST) on Indian economy", Business and Economics Journal, 7, no. 4 (2016). doi: 10.4172/2151-6219.1000264. 
[3] Morris, S., Pandey, A., Agarwalla, S. K., \& Agarwalla, A. (2018). Impact of the Proposed GST on the Consumer Price Index in India. Indian Institute of Management Udaipur Research Paper Series, (2018).

[4] John, R. M., Dauchy, E., \& Goodchild, M. (2019). Estimated impact of the GST on tobacco products in India. Tobacco Control, 28(5), 506-512. https://doi.org/ 10.1136/tobaccocontrol—0544- 579 .

[5] Sui Pheng, L. and Loi, C.P.W. (1994), "Implementation of the Goods and Services Tax (GST) in the Singapore Construction Industry", Journal of Property Finance, Vol. 5 No. 3, pp. 41-58. https://doi.org/10.1108/09588689410078593 .

[6] Cawley, J., Thow, A. M., Wen, K., \& Frisvold, D. (2019). The economics of taxes on sugar- sweetened beverages: A review of the effects on prices, sales, cross-border shopping, and consumption. Annual Review of Nutrition, 39(1). https://doi.org/10.1146/ annurev-nutr-082018-124603. annurev-nutr-082018-124603

[7] Zainal R, Teoh Chai Teng and Sulzakimin Mohamed., (2016). "Construction Costs and Housing Prices: Impact of Goods and Services Tax". International Journal of Economics and Financial Issues. 2016, 6(S7) pp.16-20.

[8] Buchanan, J.M., Tullock, G., 1975. Polluters' profits and political response: direct control versus taxes. Am. Econ. Rev. 65, 139-147.

[9] Nguyen,T.T., Pham,B.T., Prior,D., Hemmen,S.V.,(2021) Performance of tax simplification around the world: A panel frontier analysis, Socio-Economic Planning Sciences, 101154, ISSN 0038-0121, https://doi.org/10.1016/j.seps.2021.101154.

[10] Radhakrishnan,R., Madhushree L. M.\& P. S. Aithal Review on Global Implications of Goods and Service Tax and its Indian Scenario

[11] Bolton, T., \& Dollery, B. (2005). An empirical note on the comparative macroeconomic effects of the GST in Australia, Canada and New Zealand. Economic Papers: A journal of applied economics and policy, 24(1), 50-60. DOI: https://doi.org/10.1111/j.1759-3441.2005.tb00994.x.

[12] Lourdunathan, F., \& Xavier, P. (2017). A study on implementation of goods and services tax (GST) in India: Prospectus and challenges. International Journal of Applied Research, 3(1), 626-629.

[13] Govinda, Rao, M.(2000). Tax Reform in India: Achievement and Challenges. Asia-Pacific Development Journal, 7(2), 59-74.

[14] Bajpai, N., Sachs, J. D. (2000). Foreign direct investment in India: Issues and problems. HIID Development Discussion Paper No. 759, 1-21. DOI: https://doi.org/10.7916/D8F195J2. 
[15] Rao, R. K., Chakraborty, P. (2010). Goods and services tax in India: An assessment of the base. Economic and Political Weekly, 49-54.DOI: https://www.jstor.org/stable/25663968.

[16] Datey V S, GST Ready Reckoner, Taxmann Publications Pvt Ltd. New Delhi.

[17] Jain R K, Income Tax Law \& Practice, SBPD Publication,Agra.

[18] Singh Joginder, Lekhi R K, Public Finance, Kalyani publisher, New Delhi.

[19] Singh S K, Financial Accontancy, SBPD Publication, Agra.

[20] Prajapati, H. K. (2016). Challenges and Implementation of GST (Goods and Service Tax) in India. Paripex-Indian Journal of Research, 5(7), 96-98.

[21] : http://pib.gov.in

[22] www.shodhganga.inflebnet.ac.in 